\title{
Validity of static fluid practicum guide based on science process skills using kvisoft flipbook maker
}

\author{
Dinda Desma Romadona*, Sri Purwaningsih, Darmaji Darmaji \\ Universitas Jambi. Jl. Jambi - Muara Bulian No.KM. 15, Kabupaten Muaro Jambi, Jambi, Indonesia \\ Corresponding Author. Email: ddromadhona@gmail.com
}

Keywords:

Kvisoft Flipbook

Maker, Physics

Practicum Guide,

Science Process

Skills

\begin{abstract}
This study aims to develop a physics practicum guide based on science process skills on static fluid material using Kvisoft Flipbook Maker that meets valid criteria or is suitable for use. This study is development research in accordance with the ADDIE model, i.e.: Analysis, Design, Development, Implementation, and Evaluation. The science process skills indicator contained in the practicum guide is an indicator of basic and integrated science process skills by Rezba (2007). The practicum guide is validated by material and media experts and produces excellent assessment results so that it is suitable for use in the physics learning process of senior high school, especially on static fluid topic.
\end{abstract}

C2021 JSER. Universitas Negeri Yogyakarta

\section{INTRODUCTION}

Physics is a branch of science. Learning physics cannot be separated from learning about science because learning physics is the same as learning the nature of science. The essence of physics learning is not just teaching students knowledge, but physics must also be taught as a process (Salam and Arifuddin, 2018; Anggraini et al., 2016). Students can master physics learning if students are directly involved in the learning process. This is supported by the opinion of Pratiwi and Nurhidayati (2017) that learning physics, especially static fluid material, requires active student involvement by realizing direct learning experiences. To provide a direct learning experience, the learning process on static fluid material needs to be supported by practicum activities.

Practicum activities can provide concrete experiences, learning that is easier to understand, and discussions with peers so that students gain new understanding. Hamidah et al. (2014) stated that practicum is a learning strategy that can attract students' interest in developing the concepts. In addition to providing direct experience, via practicum, students are be able to develop skills. As explained by Ariyati (2010), learning through practicum is a good learning option for students to develop skills, e.g.: science process skills.

Science process skills are an approach that must be used as a reference for teachers in carrying out the learning process. Dönmez and Azizoğlu (2010) define science process skills as basic skills that facilitate student learning, make students active, develop a sense of responsibility for their own learning, increase knowledge, and help students to learn research methods. Science process skills must be nurtured and accustomed to students so that they are trained to think and work in accordance with the knowledge that they obtained (Alfian et al., 2018). Students can foster science process skills through practicum activities so that students reason scientifically and be able to develop themselves in the thinking process.

The research conducted by Yadaeni et al. (2018) showed that science process skills of students in class XII of SMAN 1 Masbagik, East Lombok on static fluid material are quite low. Furthermore, Sumiati et al. (2018) revealed that there are teachers who have not reviewed aspects of science process skills in teaching and learning activities so that students' science process skills are not measured. When carrying out practicum activities, the assessment of science process skills does not use a clear rubric and is only limited to assessing the final results of students' practicum reports (Zamista and Kaniawati, 2015). This shows that students' science process skills on static fluid material are quite low.

The low level of students' science process skills can be influenced by instructional media, such as unfocused practicum guides. Nyeneng et al. (2019) said that a complete practicum guidance based on science 
process skills was not available. In addition, most of the practicum guides used are in printed form. Practicum guides must be able to follow technological developments, especially in the world of education, especially in the new normal education era today and in the future. The use of this technology can help students absorb deeper material. Seamardi and Harimurti (2016) state that one of the technological advances in education is the use of flipbooks as a learning media.

Thus, the solution to this problem is to create a physics practicum guide based on science process skills in digital forms, such as a flipbook. One application that can produce a practicum guide in the form of a flipbook is the Kvisoft Flipbook Maker. This is in accordance with the opinion of Oktaviara and Pahlevi (2019) that the Kvisoft Flipbook Maker is a type of professional software for converting PDF files into digital books in the form of flipbooks. This application can provide a flip effect or a page that can be flipped back and forth, the display of the material is not only in the form of reading and photos, audio and video forms can be combined when presenting the material, the use of communicative applications, and the resulting product can be in stored in SWF and/or HTML formats.

Therefore, a research on the development of a physics practicum guide based on science process skills is carried out on static fluid material using the Kvisoft Flipbook Maker application. The purpose of this research is to describe the validity of the physics practicum guide based on science process skills on static fluid material using the Kvisoft Flipbook Maker. By using this learning media, it is hoped that it can provide convenience and renewal in the process of practicum activities so that students can improve their science process skills.

\section{METHOD}

This development research uses the ADDIE development model by Rusdi (2018) so that the development procedure consists of analysis, design, development, implementation, and evaluation stages. The ADDIE development model is a model that is a reference in developing and supporting effective and dynamic learning (Barokati and Annas, 2013). In this research, the development procedure is simplified to the development stage, namely development by conducting an expert validity test because at this stage the research objectives have been achieved. Thus, the procedure for developing a physics practicum guide includes the analysis stage, the design stage, and the development stage. These are explained as follows.

Analysis

The research stage for the development of a physics practicum guide based on science process skills in digital form begins with the analysis stage. The analysis stage is the basis for further stages (Muruganantham, 2015). Arkün and Akkoyunlu (2008) stated that in this step we determine the needs and differences between the knowledge, skills, and behaviors that students have. The stage carried out are i) the needs analysis in the form of material and literature analysis, and ii) student analysis in the form of student learning styles analysis.

Design

At this stage, we determine the method or plan that will be used and applied to the product development. According to Harjanta and Herlambang (2018) the design stage is a process that is carried out prior to product development. We conduct the process of designing a physics practicum guide based on science process skills on static fluid material using the Kvisoft Flipbook Maker.

\section{Development}

Products that have been designed require a response or comment through the expert validation stage as a conceptual improvement (Rusdi, 2018). This stage aims to determine the feasibility of the product developed so that the validation of the product is carried out by two expert validators, i.e.: media and material experts. Furthermore, the results obtained are in the forms of suggestions and comments that can be used as a basis for revising the product.

Table 1. Expert validation interval score range

\begin{tabular}{cc}
\hline Interval Score & Category \\
\hline $3.26-4.00$ & Very Good \\
$2.51-3.25$ & Good \\
$1.76-2.50$ & Bad \\
$1.00-1.75$ & Worse \\
\hline
\end{tabular}


After producing the physics practicum guide, an analysis of the validation data from the material and media experts is conducted. Cahyono (2017) said that the data is analyzed to determine whether the learning media meets the eligibility requirements. If these conditions are met, a quality product is obtained. The data from the experts are averaged and then categorized into interval ranges that can be seen in Table 1.

\section{RESULT}

The product developed in this study is a physics lab guide for static fluid material in digital form using the Kvisoft Flipbook Maker. In the development process, we analyze the material, previous studies, students' learning styles, and students' science process skills. The development of the practicum guide aims to support physics learning activities at the SMA/MA level and to train students' science process skills. There are four experiments included in the practical guide, namely hydrostatic pressure, Pascal's law, Archimedes' force, and the PhET simulation of hydrostatic pressure. The practicum guide contains objectives, theoretical basis, tools and materials, how to work, observations, data analysis, and conclusion.

The sections of how to work, data analysis, and conclusion contain indicators of science process skills proposed by Rezba et al. (2007). Hence, through this practicum guide students are required to be skilled in observing, communicating, classificating, measuring. concluding, predicting, variable identifying, making data tables, making graphs, describing relationships between variables, obtaining and processing data, analyzing experiments, formulating hypotheses, defining operational variables, designing experiments, and conducting experiments. The cover display of the static fluid practicum guide can be seen in Figure 1 .

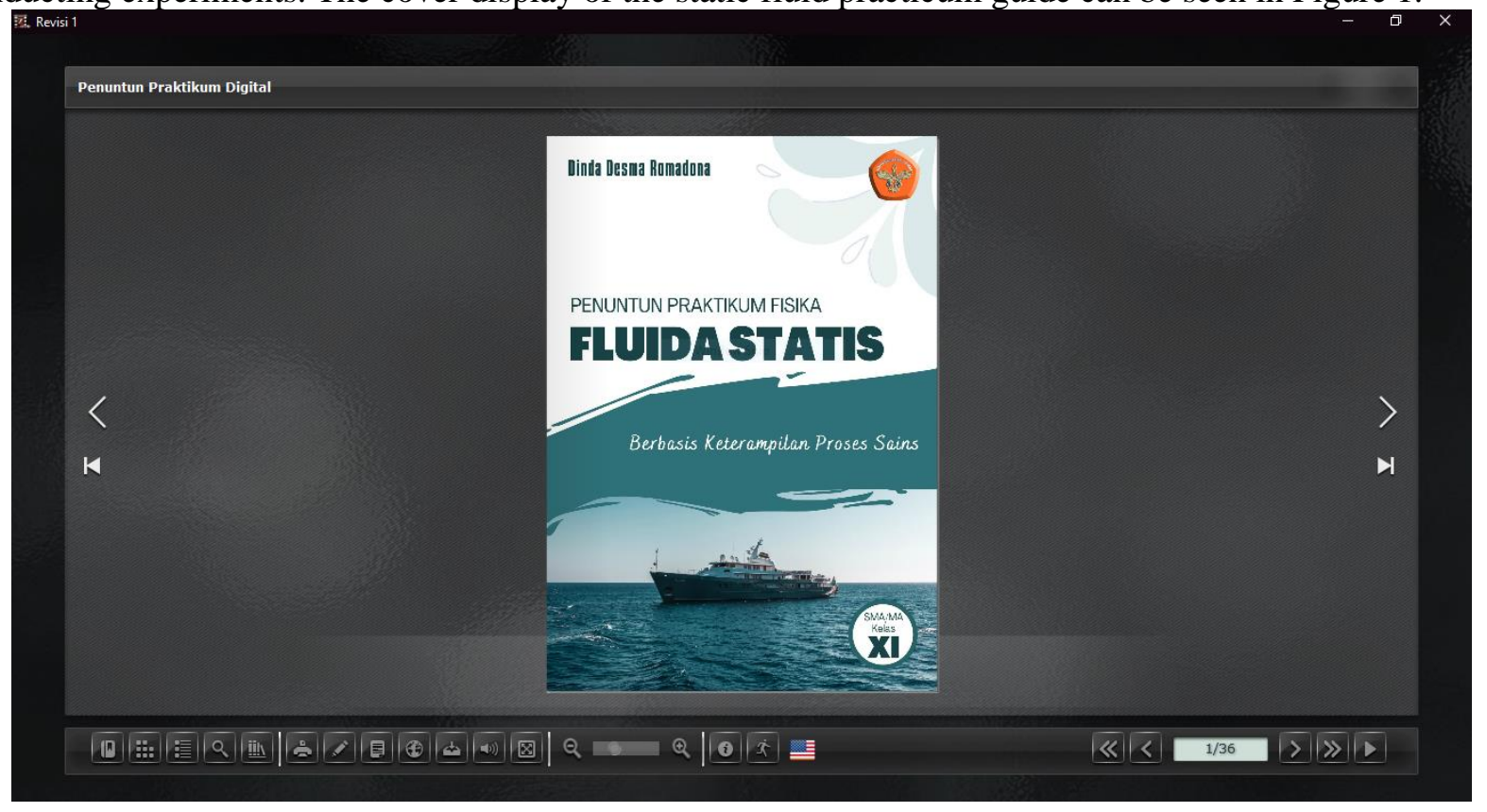

Figure 1. Cover Display of the Practicum Guide

Material and media experts have validated this practicum guide. The experts who validated this product is a physics education lecturer at Jambi University. The results of the validation of the physics practicum guide are shown in Table 2.

Table 2. Validation Results of the Practicum Guide

\begin{tabular}{|c|c|c|c|c|}
\hline Expert Validation & Assessment Aspects & Mean & Result Average & Category \\
\hline \multirow{4}{*}{ Theory } & Language & 4.00 & \multirow{4}{*}{3.73} & \multirow{4}{*}{ Very Good } \\
\hline & Contents & 3.91 & & \\
\hline & Presentation & 4.00 & & \\
\hline & Science Process Skills & 3.00 & & \\
\hline \multirow{7}{*}{ Media } & Display Screen Design & 3.75 & \multirow{7}{*}{3.46} & \multirow{7}{*}{ Very Good } \\
\hline & Ease of Operation & 3.50 & & \\
\hline & Format & 3.50 & & \\
\hline & Sound & 3.00 & & \\
\hline & Animation & 3.00 & & \\
\hline & Display Quality & 3.67 & & \\
\hline & Software Engineering & 3.50 & & \\
\hline
\end{tabular}


Based on Table 2, it can be seen that the product criteria resulted in the Very Good category with average overall scores of 3.73 and 3.46 for the material and media aspects, respectively. Thus, the physics practicum guide based on science process skills on static fluid material using the Kvisoft Flipbook Maker is suitable for physics learning process in senior high school. It is hoped that this practicum guide can be used to train students' science process skills. In addition, this practicum guide can be used in accordance to its function. Moreover, a practicum guide is one of the visual media that can be used to make students active in the learning process. Students can learn independently with the help or direction of the teacher (Alexander $e t$ al., 2018).

\section{CONCLUSION}

Physics practicum guide based on science process skills on static fluid material using the Kvisoft Flipbook Maker is declared feasible for students to be used. This practicum guide can then be used in learning physics subject in static fluid material. Hence, the physics practicum guide based on science process skills on static fluid material using the Kvisoft Flipbook Maker has a good quality; which first needs to be tested on senior high school students.

\section{REFERENCES}

Alexander, A., Rahayu, H. M., \& Kurniawan, A. D. (2018). Pengembangan Penuntun Praktikum Fotosintesis Berbasis Audio Visual Menggunakan Program Camtacia Studio di SMAN 1 Hulu Gurung. Jurnal Pendidikan Sains Indonesia (Indonesian Journal of Science Education), 6 (2), 75-82.

Alfian, H., Supeno, \& Prasutowo, S. H. B. (2018). Identifikasi Keterampilan Proses Sains Siswa SMK pada Pokok Bahasan Rangkaian Arus Sederhana. Jurnal Pembelajaran Fisika, 7 (3), 242-247.

Ariyati, E. (2010). Pembelajaran Berbasis Praktikum untuk Meningkatkan Kemampuan Berpikir Kritis Mahasiswa. Jurnal Matematika dan IPA, 1 (2), 1-12.

Arkün, S., \& Akkoyunlu, B. (2008). A Study on the Development Process of a Multimedia Learning Environment According to the ADDIE Model and Students' Opinions of the Multimedia Learning Environment. Interactive Educational Multimedia, (17), 1-19.

Barokati, N., \& Annas, F. (2013). Pengembangan Pembelajaran Berbasis Blended Learning pada Mata Kuliah Pemrograman Komputer (Studi Kasus: UNISDA Lamongan). SISFO, 4 (5), 352-359.

Cahyono, A. E. Y. (2017). Pengembangan Perangkat Pembelajaran dengan Model PBL Berorientasi pada Kemampuan Berpikir Kreatif dan Inisiatif Siswa. Pythagoras: Jurnal Pendidikan Matematika, 12 (1), $1-11$.

Dönmez, F., \& Azizoğlu, N. (2010). Investigation of The Students Science Process Skill Levels in Vocational Schools: A Case of Balıkesir. Necatibey Faculty of Education Electronic Journal of Science and Mathematics Education, 4 (2), 79-109.

Hamidah A., Sari, E. N., \& Budianingsih, R. S. (2014). Persepsi Siswa tentang Kegiatan Praktikum Biologi di Laboratorium SMA Negeri Se-Kota Jambi. Jurnal Sainmatika, 8 (1), 49-59.

Harjanta, A. T. J., \& Herlambang, B. A. (2018). Rancang Bangun Game Edukasi Pemilihan Gubernur Jateng Berbasis Android dengan Model ADDIE. Jurnal Transformatika, 16 (1), 91-97.

Muruganantham, G. (2015). Developing of E-content Package by Using ADDIE Model. International Journal of Applied Research, 1 (3), 52-54.

Nyeneng, I. D. P., Maharta, N., \& Kartika, N. (2019). Pengembangan Panduan Praktikum Berbasis Inkuiri Terbimbing pada Materi Fluida Statis. Jurnal Inovasi dan Pendidikan Fisika, 6 (2), 159-169.

Oktaviara, R.A., \& Pahlevi, T. (2019). Pengembangan E-modul Berbantuan Kvisoft Flipbook Maker Berbasis Pendekatan Saintifik pada Materi Menerapkan Pengoperasian Aplikasi Pengolah Kata Kelas X OTKP 3 SMKN 2 Blitar. Jurnal Pendidikan Administrasi Perkantoran, 7 (3), 60-65.

Pratiwi, U. \& Nurhidayati. (2017). Studi Analisis Implementasi Model POE Berbasis Inquiri Humanistik untuk Meningkatkan Higher Order Thinkng Skill (Hot Skil) Level I pada Praktikum Fisika Dasar. University Research Colloquium, 6, 101-106.

Rezba, R. J., Sprague, C., McDonnough, J. T., \& Matkins, J. J. (2007). Learning and Assessing Science Process Skills. USA: Kendall Hunt. 
Rusdi, M. (2018). Penelitian Desain dan Pengembangan Kependidikan: Konsep, Prosedur dan Sintesis Pengetahuan Baru. Depok: Rajawali Pers.

Salam, A. M. \& Arifuddin, M. (2018). Teknik Pemodelan Fisika dalam Setting Pembelajaran Berbasis Learner Autonomy. Jurnal Fisika Flux: Jurnal Ilmiah Fisika FMIPA Universitas Lambung Mangkurat, 15 (1), 47-53.

Seamardi, B. P. H. \& Harimurti, R. (2016). Penerapan Inovasi Flipbook Sebagai Media Pembelajaran untuk Meningkatkan Hasil Belajar Pengenalan PHP Kelas XI RPL di SMK Negeri 2 Mojokerto. Jurnal IT$E d u, l$ (2), 42-48.

Sumiati, E., Septian, D., \& Faizah, F. (2018). Pengembangan Modul Fisika Berbasis Scientific Approach untuk Meningkatkan Keterampilan Proses Sains Siswa. Jurnal Pendidikan Fisika dan Keilmuan, 4 (2), 75-88.

Yadaeni, A., Kusairi, S., \& Parno, P. (2018). Penguasaan Konsep dan Keterampilan Proses Sains Siswa Kelas XII pada Materi Fluida Statis. Jurnal Pendidikan: Teori, Penelitian, dan Pengembangan, 3 (3), 357-364.

Zamista, A. A., \& Kaniawati, I. (2015, October). Pengembangan Tes Keterampilan Proses Sains Materi Fluida Statis Kelas X SMA/MA. In Prosiding Seminar Nasional Fisika (E-Journal), 4, SNF2015-III. 